\title{
OPMERKINGEN OMTRENT DE VERHOOGING VAN DE BELASTING DER NAAMLOOZE VENNOOTSCHAPPEN.
}

Onder de weinig in het oog vallende maar zeker niet onbelangrijke wijzigingen die door den Minister Bertling in het door zijn ambtsvoorganger ingediend ontwerp-inkomstenbelasting zijn gebracht behoort de voorgestelde verhooging van de belasting van naamlooze vennootschappen en daarmede gelijkgestelde lichamen met bijna 82 percent. "In regel $3,2.75$ te veranderen in 5 " zoo luidt de voorgestelde wijziging van het art. 35 van het ontwerp, terwijl men in de toelichting het navolgende vindt vermeld:

„Het tarief van de naamlooze vennootschappen en andere „in art. $1 \mathrm{~b}$ en $\mathrm{c}$ vermelde vereenigingen worde verhoogd „van $f 2.75$ tot $f 5$ over elk bedrag van f 100 .

„Dit voorstel tot verhooging meent de ondergeteekende „te kunnen rechtvaardigen door een beroep op de behoeften „van de schatkist, waardoor niet enkel de physieke maar „ook de niet physieke personen en wat daarmede gelijk te "stellen is gehouden zijn belasting te betalen.

„De oprichting van de naamlooze vennootschappen "door deze wordt de belasting voornamelijk opgebracht "komt hoe langer hoe veelvuldiger voor. Kennelijk genieten „zij van de onderscheidene wetten eene zoodanige bescher"ming, dat aan haar bestaan, in het bijzonder hare aan"sprakelijkheid, de voorkeur wordt gegeven boven een "anderen vorm van vereeniging, waarbij de aansprakelijkheid "niet is beperkt. De aanvankelijk voorgestelde belasting van "f 2.75 per $f 100$. is gelijk aan de thans gehevene.

„De physieke persoon wordt door het voorgestelde ont„werp in het algemeen zwaarder getroffen; gevraagd mag "worden waarom men voor de naamlooze vennootschappen "enz. het bestaande tarief zoude moeten behouden.

"Het is waar, dat de dividenden ook bij aandeelhouders "worden in aanmerking genomen als inkomen uit vermogen, 
„maar ten eerste geldt dit alleen voor den binnen het Rijk "wonenden aandeelhouder en ten tweede moet men den „aandeelhouder niet vereenzelvigen met de naamlooze "vennootschap. Die vereeniging wijst de aandeelhouder, als "het om de aansprakelijkheid gaat, uit zich zelf beslist af."

Beknopheid is zeker een verdienste en op dit punt voldoet de toelichting aan alle redelijke eischen, maar is zij ook overtuigend?

Waar het hier geldt een verzwaring van den belastingslast voor de naamlooze vennootschappen - van de andere daarmede in het wetsontwerp gelijkgestelde lichamen zal ik kortheidshalve zwijgen - met niet minder dan 82 percent mag men inderdaad die vraag stellen. Ja, men mag zich afvragen of, zoo inderdaad verhooging der bestaande belasting noodzakelijk is, deze op de voorgestelde wijze moet worden aangebracht.

Vandaar de navolgende opmerkingen.

Geen voorgestelde hervorming is billijk te beoordeelen, zoo men zich niet vooraf een beeld heeft gevormd van het bestaande. $\mathrm{Zij}$ dit daarom met een enkel woord uiteengezet.

Volgens art. 9 D. juncto 5 der wet van 2 October 1893 (Staatsblad no 149) tot heffing eener belasting op bedrijfsen andere inkomsten wordt $f 2.50$ geheven van iedere $f 100$ van het bedrag der gewone en buitengewone uitdeelingen van welken aard ook door de naamlooze vennootschappen gedurende het belastingjaar uitgekeerd aan oprichters, concessionarissen, preferente en gewone aandeelhouders, leden en andere deelgerechtigden in de winst. Uitkeeringen, die als salaris zijn te beschouwen, bijv. tantièmes aan bestuurders zijn, niet belast en evenmin aflossingen van gestort kapitaal, die inderdaad geen winstuitdeelingen in den gewonen zin van het woord vormen.

Belasting wordt geheven van de dividenden - dit begrip om ontduiking te ontgaan wat ruim genomen - maar er is toch èène uitzondering, wijl volgens art. 5, laatste lid der wet het bedrag dat in een boekjaar, waarover de uitdeeling geschiedt, door de vennootschap is ontvangen "ter "zake van het bezit van aandeelen op naam in andere "zoodanige - dat is binnenslands gevestigde - vennoot"schappen, vereenigingen of maatschappijen" van het totaal 
der uitdeelingen waarover belasting geheven wordt, wordt afgetrokken, zulks ter vermijding van dubbele belasting.

Intusschen al is deze heffing de vrucht van den arbeid van den Minister Pierson - de geestelijke vader dezer heffing is hij niet, daar hij in hoofdzaak siechts overnam, wat reeds in tabel IX der ordonnantie op het patentrecht vastgesteld bij de wet van 6 April 1819 (Staatsblad no 34) bepaald was.

In tegenstelling van de patentbelasting van 1816 die een vast recht resp. van $f 25$, f 50 , f 100, f 200 en $f 350$ kende afhankelijk van ,hetgeen de actiën of aandeelen bij de "eerste uitgifte of succesieve uitbreiding bedragen of bedragen hebben" werd volgens tabel IX patentrecht geheven ten bedrage van "twee ten honderd van het gezamenlijk beloop „der te doene uitkeeringen, de aflossingen en accressen van "het kapitaal welke mogten plaats hebben daaronder niet "begrepen".

Ofschoon in den loop der jaren eenigzins gewijzigd ' ${ }^{1}$ ten tijde van het optreden van den Minister Pierson plachten jaarlijks 28 opcenten te worden geheven - was, toen het patentrecht ten grave daalde, er een dividendbelasting van $2 T_{100}^{56}$ percent.

Merkwaardig is het voorzeker, dat bij de scherpe veroordeeling die het patentrecht placht te ondervinden, tabel IX weinig verzet uitlokte.

Toch laat dit zich begrijpen. Immers tabel IX van het patentrecht had deze goede eigenschap, dat de verschuldigde belasting rekening hield met de resultaten van het bedrijf. Voorzeker is het inkomen van eene naamlooze vennoot-

1) Bij art. 9 der wet van 6 April 1823 (Staatsblad $n^{\circ} 14$ ) werd de belasting teruggebracht op $11 / ;$ percent, maar bij art. 8 der wet van 16 Juni 1832 (Staatsblad $n^{\circ} 30$ ) kwam men weder op twee ten honderd terug.

Aflossingen of accressen van kapitaal zouden onder de uitdeelingen zijn begrepen, maar het tweede lid van laatstgenoemd artikel bepaalde: «Nogtans zullen de maatschappijen, welke kunnen doen «blijken van hunne oorspronkelijke inlagen, mitsgaders van de «aflossingen welke daarop zijn gedaan, zoodat de werkelijke aflos«singen van het opgenomen of verstrekte kapitaal duidelijk kunnen «worden onderscheiden, de belasting niet verschuldigd zijn ter zake «van dusdanige aflossingen.» 
schap over een belastingjaar wel zelden of nooit precies gelijk aan het totaal der wegens de resultaten van het bedrijf in die periode uitgekeerde dividenden, maar verband tusschen een en ander bestaat bij bijkans ieder solied beheerde onderneming.

Voor de later, het is waar hier te lande minder dan in Duitschland, verdedigde opvatting, dat een rechtspersoon niet aan eene directe belasting zou mogen worden onderworpen, gevoelde men luttel. Integendeel, waar de uitoefening van een bedrijf in den regel medebracht, dat men belastingplichtig was, achtte men het rechtvaardig, dat ook een "corpus mysticum", zoo het een bedrijf uitoefende, aan het patentrecht werd onderworpen. Dat dit geschiedde in den vorm van een dividendbelasting, benijdde men zelfs aan die lichamen, althans later, toen men het patentrecht gaarne ook voor de physieke personen herzien zou hebben gezien in de richting van een zakelijke belasting op het werkelijk inkomen uit bedrijf. Voor dubbele belasting van hetzelfde inkomen, èèrst aan de bron bij de vennootschap, later nog eens bij de aandeelhouders behoefde men niet te vreezen, zoolang rente- of inkomstenbelastingen niet bestonden. Eerst na 1848 veranderde dit.

Reeds uit het in 1849 door den Minister van Bosse ingediende ontwerp tot heffing eener belasting tot dekking van het tekort over de jaren 1848/1849 blijkt dit. ") Nog sterker bleek deze vrees voor dubbele belasting in het door dienzelfden Minister den $22^{\text {sten }}$ Februari 1851 bij de Tweede Kamer ingediende ontwerp van wet tot heffing eener belasting op de renten van kapitalen, niet bestaande in onroerend goed noch aangelegd tot eenigen tak van nijverheid. Geheven zou worden eene belasting van $3 \mathrm{pCt}$. van

1) Voorgesteld werd eene belasting van $5 \mathrm{pCt}$. van de renten van geldleeringen ten laste van zedelijke lichamen of uitdeelingen van winst in naamlooze vennootschappen en daarmede gelijkgestelde lichamen en wel door middel van eene heffing aan de bron, dus door aanslag van de naamlooze vennootschap en niet van den aandeelhouder. Wel werd afschaffing van tabel IX van het patentrecht niet voorgesteld, maar opcenten zouden van de volgens die tabel geheven belasting $\mathrm{n}$ iet worden geheven, terwijl van andere patentplichtigen opcenten soms tot een bedrag van 80 wel werden gevorderd. 
de uitdeelingen van naamlooze vennootschappen en wel bij de vennootschap, aan de bron dus, maar afschaffing van tabel IX van het patentrecht werd in het uitzicht gesteld. $\mathrm{Na}$ een weinig gunstig Verslag werkte de Minister zijn ontwerp om. Tabel IX bleef nu gehandhaafd, maar vrijgesteld van de voorgestelde belasting zouden nu zijn "renten en "uitdeelingen op aandeelen in naamlooze maatschappijen "of zedelijke lichamen als zoodanig aan het recht van "patent onderworpen en wier kapitaal door aandeelen wordt „vertegenwoordigd". Het beginsel der wet verbood, zoo werd betoogd, "renten van kapitalen aangelegd tot eenigen tak "van nijverheid waarvan patentrecht wordt betaald" in de voorgestelde belasting te betrekken.

Het ontwerp heeft het staatsblad nooit bereikt, maar toen jaren later in het zittingsjaar 1869/1870 diezelfde Minister een algemeene inkomstenbelasting voorstelde vermeed hij zorgvuldig dubbele belasting. Ofschoon in de memorie van toelichting tabel IX van het patentrecht in tegenstelling van de andere tabellen werd geprezen, werd toch de geheele afschaffing der wet van 1819 voorgesteld.

En in denzelfden geest dacht de Minister Blussé, toen hij in 1871 zijn inkomstenbelasting voorstelde waarin naamlooze vennootschappen $\mathrm{n}$ iet werden belast.

"Gelijkstelling van corpora moralia met ingezetenen des „Rijks acht de regeering bezwaarlijk te verdedigen, omdat "het leiden moet tot dubbel emplooi."

Edoch les idées marchent, dat dubbel emplooi vreesde de Minister Gleichman minder, toen hij in het jaar 1878/1879 een ontwerp effectenbelasting verdedigde waarin aandeelen in Nederlandsche naamlooze vennootschappen onder het vermogen werden opgenomen en toch tabel IX van het patentrecht bestaan bleef. Merkwaardig is het echter hoe in de memorie van toelichting het patentrecht, dat men meer en meer was gaan beschouwen als een gebrekkige zakelijke belasting op het bedrijfsinkomen, plotseling weder was geworden "een voorwaarde tot de uitoefening van het „bedrijf". Bij de vele bescherming, die de naamlooze vennootschappen genoten, mochten zij zich zeker over de wijze waarop zij door het patentrecht werden getroffen, gelukkig prijzen, zoo werd beweerd. 
Geen wonder was het, dat zijn opvolger, de Leidsche oud-hoogleeraar Vissering, die een omwerking van het patentrecht in een belasting op bedrijfsinkomsten wilde brengen, toen hij zijn rentebelasting voorstelde, anders dacht. Hij gevoelde voor het bezwaar der dubbele belasting en wilde deze voorkomen, maar wat hij betoogde lokte wederstand uit. Men gevoelde voor dit bezwaar niet meer zooveel 'als vroeger en de Minister Grobbée stelde in het zittingsjaar $1883 / 1884$ in het ontwerp klassebelasting wèl de afschaffing van het patentrecht voor, maar nièt van tabel IX.

De dividendbelasting liet zich rechtvaardigen als - men ziet de verwantschap met hetgeen de heer Bertling thans aanvoert - als een soort betaling „voor de bizondere wette„lijke bescherming die haar - de naamlooze vennoot"schappen — beheerschen en de bescherming van wet en "recht, die zij in zoo menig opzicht verkrijgen".

Tabel IX bleef gehandhaafd en zij die beweerden, dat men op deze wijze tweemaal hetzelfde object belastte, namelijk eerst het dividend bij de maatschappij zelf in het patentrecht en later bij de aandeelhouders onder hun inkomen, kregen te hooren dat van dubbele belasting geen sprake was. "Immers treft de klassenbelasting geen object "hoegenaamd en kan zij dus ook niet gezegd worden "aandeelen in maatschappijen te treffen".

Het ontwerp-Grobbée sneuvelde, maar de daarin verdedigde leer makkte school. Toen dan ook den 2den Mei 1889 de heeren Goeman-Borgesius en anderen het terecht daarvoor weinig dankbare kabinet Mackay met hun belastingplannen verrasten werd wel de afschaffing van het patentrecht en invoering eener algemeene inkomstenbelasting voorgesteld, maar tabel IX van het patentrecht moest gehandhaafd blijven.

Als uiting van de in die dagen heerschende meening mag zeker de opmerking in de memorie van toelichting worden genoemd, dat tegen het blijven van een belasting op de dividenden alleen dàn bezwaar zou bestaan, wanneer de naamlooze vennootschappen als zoodanig in de inkomstenbelasting werden aangeslagen. Ondergebracht in een aparte wet scheen dubbele belasting tengevolge van de handhaving van tabel IX niet gevaarlijk, terwijl men tevens 
het nevenvoordeel had ook buitenlanders te treffen, die in de inkomstenbelasting niet konden worden aangeslagen.

Wanneer men gemeend zou hebben, dat zulke argumenten, die aan cassatiemiddelen in strafzaken doen denken, op een oeconoom als Mr. Pierson indruk zouden gemaakt hebben, zou men zich al zeer vergist hebben. Voor argumenten van juridischen aard gevoelde deze voortreffelijke geleerde, vooral wanneer zij meer scherpzinnig dan juist waren, weinig en zòò gemakkelijk werd bij hem de vrees voor dubbele belasting niet op de vlucht gejaagd.

Toch stelde hij in het ontwerp bedrijfsbelasting, ofschoon in de vermogensbelasting ook aandeelen in Nederlandsche naamlooze vennootschappen onder het belastbaar vermogen waren opgenomen, behoud der belastingplicht voor hier te lande gevestigde naamlooze vennootschappen voor. Maar evenals hij een koopman aan de bedrijfsbelasting wilde onderwerpen, ook al was deze voor zijn vermogen in de vermogingsbelasting belastingplichtig, zonder dat hij dubbele belasting aanwezig achtte omdat hij dien koopman toestond om van zijn inkomen uit bedrijf een bedrag gelijkstaande aan $4 \mathrm{pCt}$. van het in de zaak gestoken bedrijfskapitaal af te trekken, zoodat in de bedrijfsbelasting niet het netto inkomen van dien handelaar maar alleen zijn ondernemerswinst zou worden getroffen, evenzeer werd bij de naamlooze vennootschappen een aftrek van $4 \mathrm{pCt}$. van het gestorte aandeelenkapitaal toegestaan. Wat overbleef was de ondernemerswinst der vennootschap, dus van hen, die hun kapitaal in de onderneming hadden belegd.

Wel mocht men aarzelen of het wel juist was deze vier percent te rekenen over het gestorte aandeelenkapitaal en niet over de beurswaarde dier aandeelen, maar om practische redenen - gevreesd werd kunstmatige opdrijving der verkoopwaarde bij incourante aandeelen om van een hoog bedrag de 4 percent te kunnen in rekening brengen verdiende de gekozen weg de voorkeur.

Hoe logisch deze redeneering ook mocht zijn, instemming vond zij weinig.

Zeer vele leden wenschten volgens het Verloopig Verslag, dat de naamlooze vennootschappen over het volle dividendbelastingplichtig zouden zijn. 
Wat "zeer vele leden" verlangen is in een parlementairen staat een onafwijsbare eisch en ook de Minister Pierson moest daaraan voldoen. En hij deed het, met een gerust geweten, immers na opnieuw de quaestie der dubbele belasting onder de oogen te hebben gezien kwam hij tot de conclusie, dat die toch zoo buitengewoon niet was te vreezen, wanneer men slechts lette op de amortisatie. ') En wanneer men nu noch tevens bedacht, dat er gevaar bestond, dat de aftrek van $4 \mathrm{pCt}$. knoeiers gelegenheid bood om de heffing te ontgaan, dan was er alle aanleiding om maar met de "zeer vele leden" het bestaande systeem in hoofdzaak te handhaven.

"De bestaande patentwet", - zoo leest men in de memorie van antwoord - „is ten aanzien van naamlooze „vennootschappen een zakelijke belasting. Wordt het stelsel, „dat in het verslag verdediging vindt, wet, dan blijft dit „zoo. Op die vennootschappen blijft dan een bijzondere "last kleven, een geamortiseerde last, zooals bleek voor "de bestaande en wat de nieuwe betreft een fiscale voor"waarde aan het gebruik van dezen ondernemersvorm "verbonden".

Vandaar - want van een progressieve heffing wilde hij niet weten - het voorstel om de dividenden en daarmede

1) Een enkele zinsnede mag ils uit de memorie van antwoord, waar de vraag der amortisatie zoo gewichtig is, hier wel overnemen.

«Voor aandeelen, die reeds eenigen tijd bestaan, misschien reeds «vele malen van eigenaar hebben verwisseld, is het bestaand «patentrecht volkomen geamortiseerd. Wie een aandeel koopt weet, «dat hij $2.56 \mathrm{pCt}$. van het dividend zal missen en hij rekent daarop. «Want de waarde van cen aandeel regelt zich niet naar de winst «maar naar het dividend der maatschappij, die dit aandeel heeft «uitgegeven. De kooper van een aandeel vraagt alleen naar de *inkomsten die voor $h$ em te verwachten zijn en op deze inkomsten «heeft het patentrecht invloed.» Vandaar dat, wanneer men alleen met bestaande naamlooze vennootschappen te doen had, handhaving van het patentrecht voor de hand zou liggen. "Niet zoozeer *om het eigenaardig juridisch karakter der naamlooze vennootschap "als wel met het oog op de economische werking der belasting «waaraan zij onderworpen is, een werking in dit geval te vergelijken «met die der grondbelasting op ongebouwde eigendommen.»

In de slotwoorden ligt m. i. het zwakke van het betoog. De amortisatie werkt dikwert, maar niet, gelijk mr. Pier son aannam, steeds en automatisch. 
op èèn lijn te stellen uitkeeringen met $2 \mathrm{pCt}$. te belasten, welk cijfer later tot $2 \frac{1}{2} \mathrm{pCt}$. of juister tot $\mathrm{f} 2.50$ van elke geheele som van $\mathrm{f} 100$ is geklommen.

Daargelaten de $10 \mathrm{pCt}$. opcenten der laatste jaren is deze belasting sedert gebleven en noch de Minister de Meester in zijn wetsontwerp tot heffing eener algemeene inkomstenbelasting noch de minister, die de vader is van het thans aanhangig wetsvoorstel, brachten hierin wijziging.

Is het begrijpelijk, dat mr. Kolkman gedachtig aan het "quieta non movere" de bestaande dividendbelasting handhaafde, aan den heer Bertling, die met een scherpe verhooging komt ontvalt dit argument. Het is zelfs zaak van amortisatie niet veel te reppen. Immers treedt deze in dan is het niet dan na een gedwongen koersdaling van $2 \frac{25}{1 \overline{0}} 0$ pCt. der verkoopwaarde der aandeelen. Wordt inderdaad de inwoner - aandeelhouder in een Nederlandsche naamlooze vennootschap, die éérst over het onder zijn belastbaar inkomen opgenomen dividend inkomstenbelasting heeft te voldoen, vervolgens over de onder zijn vermogen opgenomen verkoopwaarde der aandeelen vermogensbelasting verschuldigd is en ten dérde moet ervaren, dat aan de bron, bij de vennootschap, $5 \mathrm{pCt}$. van het dividend wordt gevorderd, niet te zwaar belast?

Of moet hij bukken voor het argument, dat waar van de physieke personen een verhooging van belasting gevorderd wordt ook de niet physieke personen gehouden zijn meer te betalen? Een argument inderdaad "schlagend", mits vaststaat dat physieke en rechtspersonen op het gebied der belastingheffing op èèn lijn zijn te stellen.

Is dit echter zoo?

Op den voorgrond meen ik te mogen stellen, dat de rechtspersoonlijkheid der naamlooze vennootschappen, na langen tijd hier te lande te zijn betwist, thans vrij wel algemeen wordt aangenomen. ') Vast staat naar de meest algemeen aangenomen leer, dat het lichaam is een rechtspersoon, dat door zijne organen aan het rechtsleven, althans op het gebied van het vermogensrecht, kan deel nemen,

1) Zie het arrest van den Hoogen Raad van 18 Januari 1901 W. v. h. R. 7553 en $\mathrm{K}$ ist-Visser. Beginselen van Handelsrecht III blz. 40 ?. 
overeenkomsten treffen, verplichtingen op zich nemen in èèn woord, dat het een zelfstandig vermogen heeft afgescheiden van dat der aandeelhouders.

Hieruit volgt dan, dat de wetgever zonder dat daartegen met grond juridische bezwaren kunnen opgeworpen worden de naamlooze vennootschap aan eene directe belasting $k a n$ onderwerpen. Het rechtssubject, de persoon dien men verplichtingen kan opleggen is aanwezig. ${ }^{1}$ )

Maar het is duidelijk, dat de mogelijkheid tot belastingheffing op zich zelf de heffing niet rechtvaardigt. De mogelijkheid om een hoofdgeld in te voeren te voldoen door jeder inwoner van het Rijk bestaat zeer zeker, toch zou daarom en daarom alleen ten onzent zulk eene heffing niet gerechtvaardigd zijn!

Was trouwens het zijn van rechtspersoon reeds een voldoende grond tot belastingheffing, dan is het niet duidelijk waarom de publiek-rechterlijke rechtspersonen gelijk de Staat, provincien, gemeenten en waterschappen niet evenzeer in de belasting worden aangeslagen.

De grondbelasting geeft daar zelfs het voorbeeld.

Toch laat men deze lichamen - en $\mathrm{m}$. i. terecht - van belasting vrij. Immers tusschen deze personen en de menschen, inwoners van het rijk, bestaat zulk een essentieel verschil in karakter, dat de heffing hièr gerechtvaardigd het dààr niet meer zou zijn.

Bestaat dit essentieel verschil nu ook hier? Door de tegenstanders der belastingplicht der naamlooze vennootschappen is dit meermalen betoogd en tot onderzoek van dit argument is het noodzakelijk een oogenblik het wezen der rechtspersoonlijkheid dezer lichamen na te gaan.

In de eerste helft der XIXde eeuw heeft men zich meestal op het door den beroemden von Savigny verdedigd standpunt geplaatst, dat van nature alleen menschelijke

1) Waar die persoonlijkheid ontbreekt gelijk in den regel wordt aangenomen voor de burgerlijke maatschap staat de zaak dan ook anders. Natuurlijk kan bepaald worden, dat over de inkomsten door de in maatschap door vennooten verrichte handelingen belasting zal betaald worden, maar het zullen steeds een of meer der vennooten moeten zijn die men voor de betaling daarvan aansprakelijk stelt. Op de niet als zelfstandig wezen bestaande maatschap heeft men geen verhaal. 
wezens rechtssubject, personen, konden zijn. Edoch men kon niet blind zijn voor het feit, dat in bijkans ieder eenigszins ontwikkeld rechtssysteem ook aan niet-menschen rechten werden toegekend, verplichtingen opgelegd.

Het leven van den mensch is kort en er zijn in de samenleving verplichtingen te vervullen, die door één mensch juist om zijn sterfelijkheid niet vervuld kunnen worden.

Een vermogen wordt bijeengebracht om tot een zeker doel te dienen, een groep menschen, die hetzelfde willen, vereenigen zich, brengen arbeid of vermogen gemeen om een doel te bereiken en verlangen, dat die gemeenschap ook zal blijven bestaan, al treedt een hunner terug, al komt een ander in zijn plaats.

Dit in gemeenschap gebrachte of terzijde gelegd vermogen kan echter niet voor het doel bestemd worden, wanneer het ook niet aan het rechtsleven mag deelnemen, en waar het nu in de natuur van den mensch ligt om, zoodra men aan een recht denkt, ook een rechtssubject zich te denken, zoo wordt hier dit subject gevonden in eene kunstmatig gedachte, door het positieve recht geschapene, juridische figuur, die men rechtspersoon noemt.

$W$ ind $s$ ch e id, dien $i k$, als een van de jongste verdedigers dezer hier te lande vooral door Opzoomer en Thorbecke verdedigde leer meen te mogen aanhalen, drukt zich aldus uit: ${ }^{1}$ )

„Eine juristische Person ist nicht eine wirklich existirende „sondern nur vorgestelte Person, welche als Subject von „Rechten und Verbindlichkeiten behandelt wird. Auf diesem „Wege wird zugleich ein Bedürfnisz der juristischen Technik „befriedigt, indem es nun möglich wird den Rechtsätzen "ohne Rucksicht darauf ob die Rechte einen Subjecte zu „stehen oder nicht, einen einheitlichen Ausdruck zu geben."

De ondergrond nu van de rechtspersoon vormt ò een vermogen alleen, en in dit geval spreekt men van stichting òf een vereeniging van personen, die een vermogen bijeengebracht hebben, de corporatie. Door vele aanhangers werd geoordeeld, dat het doel, dat de rechtspersoon wilde bereiken en terwille waarvan zij werd geschapen ten

1) Windscheid Pandecten (1891) $\$ \$ 4$ en 57. 
algemeene nutte moest zijn, doch deze opvatting die vooral hier te lande ingang vond, was toch geen essentiale der leer.

Het behoeft geen betoog, dat deze leer geen algemeene instemming vond. Werd eerst door Brinz geleerd, dat men de geheele fictie kan missen en van een Doelvermogen spreken, later is door de beoefenaars van het Germaansche recht, die natuurlijk kennis hadden gemaakt met de in middeneeuwen en renaissance in tallooze vormen optredende als persoon erkende wezens, die geen menschen waren, onder voorgang van Gierke betoogd, dat men niet met eene fictie maar met een realiteit te doen had. Men mag de personen niet kunnen waarnemen - daargelaten dat het bestaan van iets nog niet afhankelijk is van de omstandigleid of de mensch wiens waarnemingsvermogen beperkt is dat kan opmerken - ook de menschelijke persoonlijkheid zou niet waarneembaar zijn.

Het recht - aan eene vereeniging of stichting de rechtspersoonlijkheid toekennende - zou in waarheid niet anders doen dan wanneer zij deze ook aan den mensch toekent.

Men kan het nalaten, evenals men het bij een slaaf soms nalaat, maar wanneer men de rechtspersoonlijkheid aanneemt creëert en fingeert men niet.

Deze leer, die op het einde der XIXe eeuw de geesten had veroverd, zoodat zij op de redactie van het Duitsche Bürgerliches Gesetzbuch van 1900 en het Zwitsersche Wetboek grooten invloed heeft uitgeoefend - is in den laatsten tiid weder bestreden - , ${ }^{1}$ ) zonder nochtans reeds het pleit verloren te hebben.

1) Door de leer der zoogenaamde propriété collective in Franlirijk inzonderheid door Planiol, hier te lande cloor prof. Molengraaff verdedigd. Naast het individuecle eigendomsrecht, dat zich ook in dier voege denken laat dat het verschillende personen aan een zelfde zaak toekomt - men denke aan meerdere erfgenamen - en dan als eigendomsrecht pro indiviso wordt erkend, heeft men het collectief eigendomsrecht. De eigenaars zijn dan te zamen eigenaar - niet eigenaars - van het geheel, zoodat zij individueel nièts, te zamen ìlles hebben. Het is hiermede als in een land, waar men de leer der volkssouvereiniteit aanneemt. Het volk, dat is de georganiseerde burgerij - niet bourgeoisie s.v.p. is eigenaar der domeinen, individueel heeft ieder burger daar geen recht op. $\mathrm{Nu}$ kan men dezen toestand in beeld brengen door te 
Het kan hier niet de plaats zijn mijn opvatting omtrent de rechtspersoonlijkheid uiteen te zetten -- ik zou voor de organische leer het meest gevoelen - dit is echter zeker, dat hoeveel overeenkomst er tusschen een physiek en rechtspersoon bestaat er toch tevens is een essentieel onderscheid. Bij beiden ontleent het wezen de persoonlijkheid aan het recht, maar bij den mensch geschiedt dit om den mensch, wiens belang dààr op den voorgrond staat. Men behoeft nog geen voorstander te zijn van een plat egoïsme en het "heb uw naaste lief als u zelve" geheel te vergeten door aan te nemen, dat de mensch bestaat voor zich zelve, al rusten ook op hem tallooze verplichtingen. Bij de rechtspersoon treedt het doel dat deze beoogt, tot vervulling waarvan zij bestaat, veel scherper op den voorgrond en dit doel ligt buiten de rechtspersoon en haar belang. Zij moge eigenaresse zijn van haar vermogen - bij de naamlooze vennootschappen is zulks mijns insziens niet slechts beeldspraak maar volgt het bepaald uit art. 56740 B. W. maar een fout is het, wanneer men bij eene corporatie met de leden, bij eene naamlooze vennootschap met de aandeelhouders, geen rekening meer houdt.

De ondergrond - ook dit is ik erken het beeldspraak, maar deze laat zich soms moeilijk vermijden - die bij een physiek persoon niet bestaat is bij de rechtspersoon wel aanwezig. Bij den persoon lette men slechts op diens belang, bij de naamlooze vennootschap mag men niet uit het oog verliezen, dat er lieden bestaan, die een vermogen in gemeenschap hebben gebracht om door geoorloofde handelingen - handel, industrie en zoo men wil ook landbouw of vermogensbezit - winst, dat is voordeel, te

zeggen, dat de personen één persoon vormen en die beeldspraak voltooien door de leden te zamen rechtspersoon te noemen in tegenstelling met de enkele menschen, de physieke personen. Beeldspraak blijft echter beeldspraak, zij kan haar nut hebben, maar wordt gevaarlijk wanneer men haar karakter vergetende aan het beeld realiteit gaat toeschrijven. M. i een volkomen juiste opmerking, doch de vraag rijst of men in ons positieve recht dit door de erkenning der rechtspersoonlijkheid niet reeds gedaan heeft. Zulk eene erkenning, of zoo men wil schepping, bij de coöperatieve vereeniging uitdrukkelijk - art. 6 der wet van 17 November 1876 Staatsblad No. 67) - elders meer verscholen kan men niet wegcijferen. 
behalen. Opdat dit doel niet verijdeld maar beter en gemakkelijker bereikt zou worden heeft het recht onder zekere voorwaarden aan het door die personen geschapene rechtspersoonlijkheid toegekend, heeft dit schepsel in het positieve recht evenals de mensch rechtsbevoegdheid, maar het gaat niet aan om de aandeelhouders, zooals de Moor, die zijn plichten heeft vervuld, eenvoudig ter zijde te schuiven. Die fout; die op zich zelf de fictie-leer niet medebracht, doch door ettelijke harer aanhangers maar te dikwijls is gepleegd, moet worden vermeden. Speciaal wanneer men zich bevindt op het terrein der "Finanzwissenschaft", waar juridische en economische wetenschap zóó ineen vloeien.

Vandaar, dat het m. i. onjuist is om uit het karakter der naamlooze vennootschap, die in de leer van von Savigny slechts een voorgesteld wezen is en niet uit vleesch en bloed bestaat, te concludeeren tot de solutie, dat deze niet werkelijk bestaande wezens niet zouden mogen worden belast. Waarom zou men niet, ook waar het belasting heffing betreft, mogen fingeeren en evenals in het burgerlijk recht het bestaan van de vennootschap als persoon aannemen?

Aan den anderen kant is het evenzeer onjuist om op grond der omstandigheid, dat de voordeelen der vennootschap aan de aandeelhouders ten goede moeten komen, dat de vennootschap bestaat voor de aandeelhouders, te betoogen, dat zulk een lichaam geen inkomen zou hebben.

Die Actiengesellschaft ist nur hinsichtlich der Production nicht hinsichtlich der Konsumtion ein wirtschaftendes Subject. ${ }^{1}$ )

Daargelaten, dat het geen essentieel kenmerk van de persoonlijkheid is of men een "wirtschaftendes Subject" is, zoo is het voor het begrip inkomen irrelevant hoe dat inkomen wordt besteed.

Ik zal mij wel hoeden hier eene definitie te geven van inkomen, iets wat ook het ontwerp inkomstenbelasting wijselijk vermijdt, maar wat daarmede bedoeld wordt is niet zeer moeilijk te omschrijven. Het totaal der resultaten der verschillende transactiën door een koopman of industrieel gedurende een zekere periode in zijn bedrijf verricht vormt

1) Felix $\mathrm{Hech}$ t. Die Staatsbesteuering der Actiëngesellschaften in Deutschland. Finanzarchiv VII blz. 45 en vlgg. 
zijn bruto bedrijfsinkomen, dat na aftrek van niet reeds in aanmerking genomen onkosten het netto inkomen wordt.

De berekening van dit inkomen is zuiver eene quaestie van techniek en of de "zaak" door een mensch of rechtspersoon wordt gedreven is voor de boekhouding geheel onverschillig.

Hoe of het inkomen besteed wordt of besteed moet worden is, waar het de vaststelling van dit inkomen betreft, weder zonder gewicht. Een ambtenaar met $f 2000$ salaris, maar die daarvan de helft aan zijn gescheiden echtgenoote moet afstaan, heeft geen minder inkomen dan zijn ambtgenoot, die hetzelfde salaris geheel naar genoegen kan besteden.

De omstandigheid, dat de naamlooze vennootschap het grootste bedrag van hare netto winsten aan de aandeelhouders moet afstaan belet niet, dat zij inkomsten heeft, winsten makt. Integendeel bij een op soliede wijze bestuurde onderneming zal in den regel de uitkeering uitblijven, zoo er geen voldoend inkomen is.

Uit dit alles volgt echter niet, dat dezelfde belastingheffing voor een physiek en rechtspersoon zou passen omdat beiden hetzelfde inkomen hebben. Reeds waar het physieke personen betreft neemt men dit niet aan - en terecht - wijl het bedrag van het inkomen wel wijst op zekere draagkracht van den dat inkomen genietenden persoon, maar toch slechts één is nevens ettelijke andere der vele symptomen waaruit een goede belastingwetgever de draagkracht afleidt.

Vandaar, dat eene bruikbare inkomstenbelasting aftrek voor minderjarige kinderen kent, rekening houdt met de renten van schulden, lijfrenten en andere uitkeeringen, die de belastingschuldige verplicht is te voldoen, ja dat men zelfs rekening houdt met onverplichte uitgaven als premiën voor levensverzekering en anderzijds, terwijl het gefundeerd inkomen, hetzij rechtstreeks hetzij door middel voor een vermogensbelasting indirect, zwaarder wordt getroffen.

Dit alles doet men om de werkelijke draagkracht zoo goed mogelijk vast te stellen, gelijk men om dezelfde redenen niet aanneemt, dat twee maal twee vier is, maar veeleer een progressief tarief invoert.

Bestaat er nu aanleiding om bij de physieke personen 
wèl, bij de rechtspersonen niet met de bizondere eigenschappen van het belastingplichtig subject rekening te houden? Deze vraag stellen is, naar het mij voorkomt, haar beantwoorden. En dan kan men $\mathrm{m}$. i. niet uit het oog verliezen, dat al is de naamlooze vennootschap de belastingplichtige, de belasting toch eigenlijk gedragen wordt door de aandeelhouders en andere deelgerechtigden in de winst, wier voordeel uit de exploitatie over een belastingjaar juist zooveel minder is als de gevorderde belasting bedraagt.

Hieruit volgt nu zeer zeker niet, dat van naamlooze vennootschappen geen, althans minder belasting geheven zou moeten worden dan van physieke personen maar wel, dat men zal moeten nagaan of inderdaad de vroeger zoo zeer bestaande vrees voor dubbele belasting - men denke aan de uitspraak van den minister Blussé - een hersenschim is.

Uit den aard der zaak is dit afhankelijk van de wijze waarop die aandeelhouders belast worden. Bestaat er wel een kapitaalrente of algemeene inkomstenbelasting, maar stelt men de aandeelhouders met hun aandeelenkapitaal of de genoten dividenden vrij, omdat de vennootschap belastingplichtig is, dan is van dubbele belasting geen sprake.

Maar ook wanneer die er mocht zijn, is zij daarom nog niet ongerechtvaardigd.

In een land, waar naast de algemeene inkomstenbelasting nog een bedrijfsbelasting, een "Gewerbesteuer", bestaat waaraan de naamlooze vennootschappen evenals andere industrieelen of kooplieden worden onderworpen, is er wel dubbele belasting, wijl de aandeelhouders over hun dividend inkomstenbelasting betalen - immers dit wordt opgenomen onder hun inkomen - en daarnevens ten slotte de bedrijfsbelasting hebben te dragen - immers hunne voordeelen uit het bedrijf worden verminderd met wat de maatschappij aan bedrijfsbelasting heeft te betalen. Waar de aandeelhouders gelijk de bekende hoogleeraar Sch a n $\mathrm{z}$ het terecht zegt echter "Gewerbtreibende sind, welche einen gewerblichen Beruf "haben den sie durch bezahlte Organe-leiten lassen" 1) is het volkomen billijk, dat zij met de andere handel en industrie drijvenden op één lijn gesteld worden.

1) Schanz. Zur Frage der Steuerpflicht Finanzarchiv IX blz. 54 . 
Ik ga verder. Gelijk in Pruissen sedert de hervorming van $M$ iquel rechtens is en thans hier te lande wordt voorgesteld, zal men aan den rechtmatigen eisch om het gefundeerd inkomen zwaarder te belasten dan het ongefundeerde voldoen door nevens de algemeene inkomstenbelasting nog een kapitaal of vermogensbelasting te heffen. Dat men onder dat belastbaar vermogen ook de aandeelen in binnenlandsche naamlooze vennootschappen begrijpt is niet meer dan billijk. Immers beschouwd als vermogen zijn aandeelen in binnenlandsche naamlooze vennootschappen niet minder bestanddeelen van iemands vermogen dan aandeelen in buitenlandsche maatschappijen, obligatiën, hypotheekschulden, pandbrieven enz.

$\mathrm{Er}$ is geen essentieel verschil en dit ontstaat ook niet doordat men naast de inkomsten- en aanvullings- scil-vermogens-belastingen nog een afzonderlijke bedrijfsbelasting heft waaraan de naamlooze vennootschappén zijn onderworpen. Zeker het gevaar voor dubbele belasting bestaat, voor driedubbele zelfs, maar niet de dubbele belasting op zich zelf is onrechtmatig maar die, welke zich $n$ iet laat motiveeren.

Evenals nu een vermogensbelasting naast een algemeene inkomstenbelasting zich laat rechtvaardigen, zoo is het ook met de hierbedoelde bedrijfsbelasting.

Niet zoozeer op grond der offertheorie en de daarop steunende leus van belasting naar draagkracht - ofschoon gelijk ik beneden hoop aan te toonen ook hier wel steun is te vinden - als wel, omdat het publiek gezag, de staat en bij de gemeente treedt dit nog meer op den voorgrond aan handel en industrie, speciaal, wanneer die op grooten schaal worden uitgeoefend, telkens diensten bewijst, waarvan anderen niet of veel minder genieten. Van daar een afzonderlijke belasting - een Gewerbesteuer — waarvan men de kleinere nijverheid en handel zonder bezwaar kan vrijlaten omdat in een goed geregeld belastingstelsel deze voor die diensten reeds betalen wat naar billijkheid, hun draagkracht in aanmerking genomen, van hen kan gevorderd worden. Bij de grootindustrie, bij den groothandel is dit anders, hier zijn de diensten relatief grooter, maar is ook de draagkracht sterker. Zelfs in perioden van depressie valt, zoo slechts voor een goede reserve is gezorgd, de belastingbetaling niet zoo zwaar. 
Of het echter billijk is niet de grootindustrie of groothandel maar speciaal de naamlooze vennootschappen aan zulk een bedrijfsbelasting te onderwerpen - en dit geschiedt ten onzent, want al moge de voorgestelde dividendbelasting een plaats vinden in de wet op de inkomstenbelasting haar karakter van zakelijke belasting, Realsteuer, der naamlooze vennootschappen geheven over de dividenden verliest zij daardoor niet - is een andere vraag. Niet alle naamlooze vennootschappen oefenen althans hier te lande het bedrijf op grooten schaal uit en al ware dit het geval, is er wel voldoende aanleiding om, wanneer verschillende volstrekt niet altijd bemiddelde personen te zamen door middel eener naamlooze vennootschap de vruchten van een bedrijf genieten, hen te belasten, terwijl men den eigenaar-fabrikant-grootindustrieel niet belast?

lk geloof, dat desniettemin die vraag to estemmend beantwoord kan worden, alleen wat mr. Pierson indertijd ter verdediging der bedrijfsbelasting aanvoerde kan nu voor het voorstel van den heer Bertling die eene verhooging van 2. $\left(2 \frac{75}{100}\right)$ tot $5 \mathrm{pCt}$. voorstelt niet dienen.

Immers het argument van den heer Pierson was dat de dividendbelasting van het patentrecht eerst 2 , later $2 \frac{56}{100} \mathrm{pCt}$. geamortiseerd zou zijn. Neem aan, dat dit juist is, des neen, dan zal daaruit kunnen volgen, dat wanneer maar eenmaal de belasting tot $5 \mathrm{pCt}$. is opgevoerd ook dit bedrag geamortiseerd zal worden, maar daardoor is toch zeker de verhooging die dan op een kapitalverlies van $2, \frac{25}{100} \mathrm{pCt}$. neerkomt niet gerechtvaardigd.

De heer Pierson evenals mr. Kolkman handhaafden het bestaande en mochten zich daarom op een dergelijk argument - aangenomen dat dit juist is - beroepen, voor het voorstel van den heer Bertling pleit het niet.

Krachtiger lijkt mij het andere argument dat volgens den Minister Pierson voor nieuw op te richten naamlooze vennootschappen zou gelden, dat de belasting de fiscale voorwaarde zou zijn aan het gebruik van dezen ondernemersvorm gebonden.

Ofschoon ik niet zou medegaan met het betoog, dat dergelijke rechtsdiensten in den rechtstaat gratis verleend zouden moeten worden, te duur moet men ze toch ook 
niet in rekening brengen. Immers wanneer ons recht de naamlooze vennootschappen - en hoe gebrekkig! - regelt en dus gelegenheid schept om van dezen ondernemersvorm gebruik te maken, geschiedt dit toch niet in de eerste plaats ter wille der aandeelhouders, maar ter wille van het algemeen belang.

Het is daarmede als met het vele nuttige dat men in het leger den miliciens leert. Het is verdienstelijk, en die verdienste wordt vaak miskend, maar ten slotte leert men dit alles den miliciens toch niet in de eerste plaats ter wille van hen zelf.

Een matige heffing, al brengt zij ook dubbele belasting, laat zich verdedigen, want door de beperking der aansprakelijkheid der aandeelhouders tot het bedrag der aandeelen geeft men aan tal van personen gelegenheid aan handel en industrie deel te nemen, wat anders voor hen te gevaarlijk zou zijn. En in zooverre heeft de Minister Bertling, die op de beperking der aansprakelijkheid der aandeelhouders wijst, volkomen gelijk.

Edoch het is duidelijk, dat zich op dezen grond niet iedere heffing laat rechtvaardigen. Wanneer het Rijk van iedere f 100 dividend $\mathrm{f} 5$ eischt, dus grosso modo $5 \mathrm{pCt}$. vordert en aan de gemeenten daarenboven de gelegenheid wordt gelaten om een bedrag van 100 , ja 160 , opcenten te heffen - en zulk eene opcentenheffing is gerechtvaardigd, wanneer men bedenkt hoeveel lasten elke naamlooze vennootschap, die veel lieden in haar dienst heeft op de schouders legt van de gemeente, waar zij haar bedrijf uitoefent en hare arbeiders gevestigd zijn - dan is men spoedig genaderd tot een dividendbelasting van $10 \mathrm{pCt}$. Zulk eene heffing is echter zòò hoog dat zij - in Oostenrijk, speciaal in Zuid-Tirol, is dit duidelijk merkbaar - de oprichting en instandhouding van naamlooze vennootschappen belemmert.

Op zich zelf is dit niet altijd een nadeel, tallooze kleine naamlooze vennootschappen doen $\mathrm{m}$. i. meer kwaad dan goed, maar het kan een nadeel zijn en het is een nadeel, wanneer er door veroorzaakt wordt, dat zich ergens tengevolge van den belastingdruk een industrie niet ontwikkelen kan, al zijn de overige gegevens voor eene goede ontwikkeling aanwezig. 
Toch is het begrijpelijk, dat de Minister van Financiën versterking der middelen noodig hebbende en zonder dat blijkt, dat hij de gemeenten in de toekomst de mogelijkheid van heffing van opcenten wil ontnemen, verhooging der bestaande dividendbelasting voorstelt.

Het is waar, men zou reeds door omwerking van een dividendbelasting in een zuivere belasting op het inkomen, gelijk deze in vele Duitsche Staten bestaat, een hoogere opbrengst kunnen verkrijgen. ${ }^{1}$ )

Van de thans gemaakte winst wordt dikwerf een goed deel niet als dividend uitgekeerd maar in reserve-fondsen opgeborgen of voor uitbreiding der onderneming besteed.

Waar, zooals bij kleinere naamlooze vennootschappen menigmaal geschiedt, de aandeeler in èèn hand, althans in weinig handen zijn, geschiedt dit meermalen.

Door niet of weinig dividend uit te keeren spaart men belasting, maar met de waarde van het maatschappelijk kapitaal rijst de verkoopwaarde der aandeelen. Op den duur, b.v. bij overlijden van den aandeelhouder zal de fiscus in een hooger bedrag waarover successiebelasting kan worden geheven zekere schadeloosstelling vinden maar vooralsnog spaart men toch belasting. Dat er onder de 4486 naamlooze vennootschappen, die in het belastingjaar 1911/1912 niet in de bedrijfsbelasting werden aangeslagen, maar zeer enkelen zouden zijn, die omdat zij geen uitdeelingen deden van een aanslag bevrijd zijn gebleven, maar die desniettemin wel een inkomen van beteekenis gehad hebben, is nog te betwijfelen. Toch geloof ik niet, dat zulk een technische wijziging den Minister de gelden zou brengen die hij noodig heeft. Ofschoon voor den tegenwoordigen Minister het argument niet kan gelden, dat zijn ambtsvoorganger gebruikte, dat hij de belasting inzonderheid handhaafde omdat die nu eenmaal bestond, lijkt mij desniettemin het

1) Het dikwerf gehoord bezwaar, dat naarnlooze vennootschappen geen inkomen in den waren zin van het woord zouden hebben, daar zij geen persoonlijke behoeften hebben en evenmin een eigen doel - zie Fuisting. Die Einkommensteuer der Zukunft. 1903 blz. 12 is boven reeds besproken. Technisch zal men het «inkomen» bij naamlooze vennootschappen, omdat veel nauwkeuriger boek pleegt gehouden te worden, integendeel gemakkelijker kunnen vaststellen dan het inkomen van physieke personen. 
vasthouden aan een dividendbelasting gerechtvaardigd. ') Immers juist door deze belasting heeft men de gelegenheid de aandeelhouders dàn te treffen, wanneer de belasting hen het minst deert, wanneer hun draagkraclit het grootste is.

Dit toch verlieze men niet uit het oog; draagkracht is een relatief begrip. Iemands draagkracht om belasting te voldoen is afhankelijk van zijn totaal inkomen, maar volstrekt niet daarvan alleen.

Die een prijs in eene loterij wint zal daarvan gemakkelijker een deel kunnen afstaan dan van een wellicht met moeite verdiend salaris. Duizend gulden is niet altijd duizend gulden.

Waar nu de uitkeeringen bij naamlooze vennootschappen, die hooge dividenden kunnen uitkeeren, min of meer het karakter vertoonen van prijzen in een loterij is voor hen, die deze uitkeeringen genieten, de belastingdruk minder groot.

Als regel - er is natuurlijk geen regel zonder uitzondering - is het bij een hoog dividend min of meer onzeker of dit over een volgend jaar kan worden uitgekeerd. In dergelijke fondsen is veel speculatie, wanneer de aandeelen ter beurze verhandeld worden ziet men menigmaal scherpe schommelingen in de verkoopprijzen. Natuurlijk houdt de beurswaarde ook van deze effecten verband met den algemeenen rentestandaard. Maar wanneer men een rente van $4 \mathrm{pCt}$. als de normale aanneemt, zal men toch zien, dat cen aandeel nominaal groot $f 1000$, waarop $f 200$ dividend is uitgekeerd, niet ter beurze voor f 5000 zal verhandeld worden maar voor een lager bedrag. De aandeelhouder die 20 pCt. dividend ontvangt beschouwt een goed deel daarvan niet als kapitaalrente, maar als een meer toevallige bate, afwisselend van de kansen van het bedrijf. Dat deel vertoont veel overeenkomst met ondernemerswinst, zij het ook genoten door lieden, die slechts indirect, niet rechtstreeks, ondernemer zijn.

Evenzoo als bij inkomen uit kapitaal in den regel de belastingdruk minder gevoeld wordt dan bij inkomen uit

1) Bijlagen 1912/13 44. 2 blz. 4. Natuurlijk dat minister Bertling zich hoedt gebruik te maken van het argument der amortisatie waarop de heer Pierson zich beriep. Zoodra men met een verhooging van het tarief komt is de amortisatie-leer een tweesnijdend zwaard. 
arbeid, evenzoo valt een offer van deze ondernemerswinst - sit venia verbo - gemakkelijker dan van gewone rente. Natuurlijk gaat dit niet altijd op, maar dit is ook niet steeds, waar het arbeids- en kapitaalinkomen betreft, het geval. Toch maakt de wet - het thans aanhangig ontwerp wel is waar slechts indirect door handhaving van de vermogensbelasting - tusschen beide soorten van inkomsten onderscheid en terecht want de wetgever moet zijne regelen geven in overeenstemming met wat meestal, nièt met wat slechts bij uitzondering geschiedt.

Hoe grooter het dividendspercentage is, des te gemakkelijk is voor de aandeelhouders de belasting te dragen en vandaar, dat hier voor een progressief tarief, dat daarmede rekening houdt wel plaats is.

Bij deze beschouwingen is slechts gelet op de aandeelhouders, niet op de vennootschap zelve, op de rechtspersoon.

Inderdaad, een gevoel van belastingdruk zal een niet menschelijk wezen wel niet hebben. Maar dit neemt niet weg, dat in een bloeiende zaak - en waar hooge dividenden worden uitgekeerd zal men bij een solied beheerde onderneming ook wel als regel met een bloeiende zaak te doen hebben - de fiscus scherper kan toegrijpen zonder dat zijn eischen het bedrijf hinderen dan wanneer men met moeite verhindert, dat het bedriifsjaar met een nadeelig saldo sluit.

Wanneer een maatschappij een aandeelenkapitaal heeft van 50 millioen en slechts $f 50.000$ voor dividend beschikbaar is, is een belasting van 5 ten honderd, dus van $\mathrm{f} 25.000$ niet zonder beteekenis. Hier wordt iedere gulden belasting als een offer gevoeld, nuttige verbeteringen worden daardoor al spoedig, zoo niet verhinderd, dan toch bemoeilijkt.

Wat beteekent echter $f 25.000$ voor een onderneming waar een half millioen netto winst is gemaakt en het geheele aandeelenkapitaal slechts vijfmaal zooveel bedraagt?

Ook de dividend belasting kan drukkend worden. Het is hiermede als met de tienden, die, wat men ook over amortisatie van dien last mocht spreken, in jaren van slechten oogst en lage prijzen der producten wel degelijk op de grondeigenaars drukten. Ook de dividendbelasting heeft haar grens.

Vandaar, dat de vraag rijst of men niet verstandig zou doen om, waar nu eenmaal belastingverhooging met het 
oog op de behoeften der schatkist onvermijdelijk is, de voorgestelde verhooging der dividendbelasting tot $5 \mathrm{pCt}$., tot eene van $3 \mathrm{pCt}$. of $\mathrm{f} 3$ van eene $\mathrm{f} 100$ te beperken.

Daarnevens zou men evenwel, wanneer eerst het belastbaar inkomen - dus het totaal van het dividend en wat daarmede gelijkgesteld is - met $4 \mathrm{pCt}$. van het gestort aandeelenkapitaal is verminderd, over dat overschot eene belasting kunnen heffen van $2 \mathrm{pCt}$. en daarenboven, voorzooverre het dividend 6 ten honderd van het gestort aandeelenkapitaal overtreft, eene van $4 \mathrm{pCt} .{ }^{1}$ ) Dit overschot, dat doet denken aan de ondernemerswinst die de minister Pierson oorspronkelijk met $3 \frac{2}{1 \overline{0}} \mathrm{pCt}$. wilde belasten, wordt dan zwaarder getroffen. Voor zooverre het dividend blijft beneden de normale rente voor uitgeleend kapitaal is de belastingdruk veel minder dan de regeering thans voorstelt.

Een voorbeeld moge dit ophelderen.

Stel een naamlooze vennootschap met een volgestort aanideelenkapitaal van $f 1.000 .000$ keert 10 pCt. of $f 100.000$ dividend uit.

Bij een belasting van $5 \mathrm{pCt}$. is $\mathrm{f} 5000$ verschuldigd.

Volgens het hierboven verdedigde plan:

1e. 3 pCt. van $\mathrm{f} 100.000$. . . . . . . . . $=\mathrm{f} 3000$

$2^{\text {e. } 2 " ~ " ~} " 100.000-40.000$ of van $f 60.000=, 1200$

3е. $4 \quad " \quad " 100.000-60.000 ", " 40.000=, 1600$

f 5800

of $5, \frac{R}{10} \mathrm{pCt}$, dus iets meer dan volgens het voorstel van den heer Bertling. Stelt men de uitkeering op 8 percent dan wordt in beide gevallen juist $5 \mathrm{pCt}$. belasting geheven.

Bij eene uitdeeling van $7 \mathrm{pCt}$. dividend is volgens het hierverdedigde tarief verschuldigd $44_{T_{0}^{+3}}^{+3} \mathrm{pCt}$, bij een uitdeeling van $6 \mathrm{pCt}$. $3 \frac{\pi_{6}}{7_{0}} \mathrm{pCt}$. bij eene van 5 percent $3 \frac{{ }_{1}^{4}}{10} \mathrm{pCt}$. terwijl bij eene uitkeering van $4 \mathrm{pC}$. of minder slechts $3 \mathrm{pCt}$. belasting gevorderd wordt.

Bij hooge dividenduitkeeringen is het belasting percentage hooger. Zoo bij eene uitkeering van $20 \mathrm{pCt}$. $7 \frac{4}{10} \mathrm{pCt}$., bij eene van $15 \mathrm{pCt}$. $\pm 6 \frac{6_{10}^{86}}{0} \mathrm{pCt}$. Maar bij lage dividenden, dus

1) $4 \mathrm{pCt}$, omdat dit de normale rente geacht kan worden dic men bij belegging in soliede obligatiën kan verkrijgen. Fen aftrek van 5 pCt. zou te hoog zijn. 
wanneer in den regel de zaak niet zoo bloeiend is, is het tegendeel het geval, zoodat er dan gelegenheid blijft locale opcenten ten behoeve der gemeenten te heffen tot een vrij aanzienlijk bedrag zonder de vennootschap onder de belasting te bedelven.

Een opcentenheffing van $100 \mathrm{pCt}$. zal tengevolge hebben, dat bij een tarief als het hier voorgestelde toch niet meer dan $6 \mathrm{pCt}$. gevorderd wordt, terwijl volgens het wetsvoorstel dan $10 \mathrm{pCt}$. wordt geeischt of wanneer 160 opcenten voor de gemeente geheven worden $13 \mathrm{pCt}$., wat aan Oostenrijksche toestanden doet denken.

Het te hoog oploopen der belasting door de locale opcenten kan men daarenboven gemakkelijk tegengaan door te bepalen, dat de gemeenten alleen opcenten mogen heffen over dat gedeelte van het belastbaar inkomen waarover 3 pCt. belasting geheven wordt. De gemeente opcenten verliezen daardoor alle progressief karakter en terecht, daar deze belasting ten opzichte der gemeente is te beschouwen als in hoofdzaak eene vergoeding voor bewezen diensten, die dikwerf juist bij weinig bloeiende ondernemingen het gewichtigst zijn.

Ook hier moge een voorbeeld ter verduidelijking strekken.

Stel men heft 100 opcenten ten behoeve der gemeente. Bij een dividend van $4 \mathrm{pCt}$. over een gestort aandeelen kapitaal van $\mathrm{f} 1.000 .000$ is verschuldigd volgens het voorstel van Minister Bertling f 4000 of 10 percent waarvan f 2000 voor het Rijk en $\mathrm{f} 2000$ voor de gemeente. Volgens het zooeven aanbevolen tarief is verschuldigd f 2400 waarvan f 1200 voor het Rijk en f 1200 voor de gemeente. Niet $10 \mathrm{pCt}$. maar slechts $6 \mathrm{pCt}$. wordt in het geheel aan belasting gevorderd.

Bij een dividend van $10 \mathrm{pCt}$. verschillen echter de cijfers. $\mathrm{Nu}$ zal gevorderd worden $\mathrm{f} 5800$ voor het Rijk en $\mathrm{f} 3000$ voor de gemeente dus in toto 8800 of $8 r_{10}^{8}$. Juist omdat de opcenten voor de gemeenten, zelfs al stelt men ze op 100, toch slechts gelegd worden op een matige heffing van 3 pCt. zullen zij niet zoo zwaar drukken als bij het voorstel der regeering.

Natuur!ijk geef ik het boven aangeduid tarief gaarne voor een beter. Het is ontleend aan de Oostenrijksche wet van 25 October 1896 maar iets hooger, want ten onzent be- 
hoeft men gelukkig niet met een normale heffing van 10 pCt. rekening te houden. ')

Trouwens men behoeft niet naar het buitenland te gaan om reeds eene heffing in den geest van hetgeen hier voorgesteld wordt te vinden. De Nederlandsch-Indische inkomstenbelasting van 1908 bevatte reeds eene regeling in den hier aangegeven zin, die in 1912 wel gewijzigd is, maar met behoud van het beginsel.

Volgens de ordonnantie op de inkomstenbelasting, zooals deze na de wijzigingen in I. S. 1913 no 182 aangebracht luidt, wordt van de in Nederl. Indië gevestigde naamlooze vennootschappen thans geheven belasting $1^{\circ}$ op het jaarlijksch zuiver inkomen en wel van 3 percent en $2^{\circ}$ op de overwinst en wel van 6 percent.

Die overwinst wordt gevonden door het bedrag der belastbare verdeelingen - dividenden en wat daarmede gelijk gesteld is - over een kalenderjaar te verminderen met 5 percent van het gestort aandeelen kapitaal.

De gelegenheid bestaat dus om na te gaan hoe zulk een belasting gewerkt heeft en wanneer men dan ziet, wat dienaangaande bij de behandeling der Staatsbegrooting van Nederl. Indië voor 1913 is voorgevallen, blijkt, dat er in 1908 fouten zijn gemaakt, die eene wijziging der toen ingediende regeling noodzakelijk maakten, maar dat de Indische regeering de belasting der "overwinst" niet wilde missen.

De fouten door de ervaring aan het licht gekomen kan men thans ontgaan, in principe is de ondeugdelijkheid van de in Indië geldende regeling niet aangetoond. Het tegendeel is het geval. ${ }^{2}$ )

1) Volgens $\$ 100$ der wet van 25 October 1896 Finanzarchiv XIV blz. 144 zijn daar te lande de naamlooze vennootschappen onderworpen aan een Erwerbsteuer bedragende $10 \mathrm{pCt}$. der netto winst. Daarnevens geldt dan: Alstiëngesellschaften, welche für das der Besteuering zu Grunde gelegte Jahr mehr als 10 pCt. an Dividend vom eingezahlten Aktiënkapital verteilen, haben ausser der in der vorstehender abs. $1-5$ berechneten Steuer vom demjenigen zur Vertheilung gelangenden Betrage welche für das 11-15 $\mathrm{pCt}$. der Dividende erfvorderlich ist $2 \mathrm{pCt}$., von dem darüber hinaus zur Verteilung gelangenden Betrage $4 \mathrm{pCt}$. zu entrichten.

$\left.{ }^{2}\right)$ De tekst der Indische belastingverordening zooals die vưurr de jongste wijziging van 1913 gold vindt men bij mr. L. A. C. Ecory. 1914. 
Vandaar dat men zich moet hoeden om ter berekening van de "overwinst" - het zij geoorloofd de inderdaad niet zeer gelukkige Indische uitdrukking over te nemen - een te hoog percentage van het gestort aandeelenkapitaal voor

Kolff. De Inkomstenbelasting van naamlooze vennootschapeen (1912). De oorspronkelijke regeling indertijd door den toenmaligen Minister van Koloniën mr. Fock met animo in de Staten-Generaal verdedigd verschilt van de thans geldende hicrin, dat ter berekening der "overwinst" het totaal der uitgekcerde dividenden niet alleen verminderd werd met $5 \mathrm{pCt}$. van het gestort aandeelenkapitaal, maar dat die aftrek ook berekend mocht worden over maatschappelijk lapitaal in het bedrijf angewend en ontstaan uit voor de inwerkingtreding der ordonnantie niet uitgekeerde winsten. Bij vele ondernemingen was dit maatschappelijk kapitaal aanzienlijk, overtrof het soms zelfs het op de aandeelen gestorte kapitaal. Vandaar dat $5 \mathrm{pCt}$. van het bedrag waarover de aftrek berekend werd zirí groot was, dat de «overwinst» grootendeels verdween.

Ten onrechte had men in 1908 deze aftrek aldus geregeld. Het percentage van het dividend richt zich niet naar het maatschappelijk maar naar het op de aandeelen gestort kapitaal. De overwinst belasting berust op de gedachte, dat bij hooge dividenden eene hoogere belasting gerechtvaardigd is. Men behoort dus ook alleen na te gaan of het dividend hoog is en daarmede alleen is rekening te houden. De waarde van het maatschappelijk kapitaal doet evenmin als de verkoopwarcle der aandeelen ter zake.

De fout, waarin men vervallen was door toe te geven aan een vermeende eisch der billijkheid, is thans hersteld. In de tweede plaats had men in 1908 een progressief tarief klinmende van 1 tot 6 percent. De 6 percent werd echter alleen geheven over dat gedeelte der overwinst dat meer bedroeg dan 8 percent van het op de boven aangegeven wijze berekend "gestort» kapitaal. Bij vele maatschappijen kwam men echter nimmer tot de mogelijkheid om 6 pCt. te kunnen berekenen. Thans wordt, nadat het dividend met $5 \mathrm{pCt}$. van het gestorte aandeelenkapitaal is verminderd, over dit overschot dadelijk en steeds 6 percent geheven. Natuurlijk dat dit meer opbrengt dan de vroegere heffing die nimmer $6 \mathrm{pCt}$. bereikte. Toch is de belasting progressief gebleven, zij het ook, dat men nu met een ander systeem van progressie te doen heeft. Stel dat men te doen heeft met twee vennootschappen waarvan de eerste, die een gestort aandeelenkapitaal van $\{1.000 .000$ heeft $6 \mathrm{pCt}$., de andere met een gestort aandeelenkapitaal van $\mathrm{f} 500.00012 \mathrm{pCt}$. dividend kan uitkeeren. De belasting der overwinst is nu in het eerste geval $\mathrm{f} 600$ of 1 percent en het andere $\mathrm{f} 2100$ of $3 \frac{1}{2} \mathrm{pCt}$. van het geheele dividend. Men ziet de heffing is ook thans nog niet overdreven.

Over de geschiedenis der Indische inkomstenbelasting zie men Handelingen der Staten-Generaal 1912/1913 Bijlagen 4 No. 7 . 
aftrek in aanmerking te doen komen. Met het oog op den rentevoet in Indië moest men daar wel een aftrek van $5 \mathrm{pCt}$. toelaten. Hier te lande schijnt 4 pCt., de rente die men bij belegging in soliede staatsfondsen pleegt te maken,voldoende en een hooger percentage te nemen zou een ernstige fout opleveren. Bij de vaststelling van het tarief zal men, hetzij men de Benthamsche progressie aanneemt, gelijk thans in Indië het geval is, hetzij eene andere, niet uit het oog moeten verliezen, dat men niet met een te laag percentage mag beginnen. Waar zeer hooge dividenden toch uitzondering zijn is daaruit de schatkist niet voldoende te vullen.

Het is natuurlijk zeer moeilijk om na te gaan of een tarief gelijk in dit opstel ter overweging wordt gegeven ten slotte voor den fiscus veel onvoordeeliger zal zijn dan de voorgestelde verhooging der belasting - wanneer men de opcenten ter zijde laat - met 100 percent.

Bij vennootschappen, die niet in bloeienden toestand verkeeren zal de belasting van $3 \mathrm{pCt}$. natuurlijk minder opbrengen dan eene van 5 ten honderd. Edoch wanneer men de "Jaarcijfers" over 1912, de laatste die ik kon raadplegen, opslaat en op blz. 191 vermeld vindt, dat in 1911/1912 van de 7660 hier te lande haar zetel hebbende naamlooze vennootschappen 3174 uitkeeringen hebben gedaan en wel gemiddeld $11.55 \mathrm{pCt}$. van het gestort kapitaal, dan vraagt men zich af of de schade, wanneer bij eene uitkeering van $10 \mathrm{pCt}$. reeds $5, \frac{8}{1}$ percent belasting, bij eene van $11 \mathrm{pCt}$. $6 \frac{09}{100} \mathrm{pCt}$. wordt geheven, inderdaad zòò groot is, dat daarom reeds alleen het plan verwerpelijk zoude zijn. ${ }^{1}$ )

Het hoofdbezwaar tegen eene belasting in den hier bedoelden geest schijnt nog te bestaan in de mogelijkheid om door verwatering van het aandeelenkapitaal de „overwinst" te doen verdwijnen. Edoch, zoolang de belasting zich binnen redelijke grenzen houdt, zijn de voordeelen die een relatief gering aandeelenkapitaal en een hooge dividend-

blz. $83, N^{\circ} .41$ blz. $39, N^{\circ} 42$ blz. 65 en vlgg. en in de Handelin-

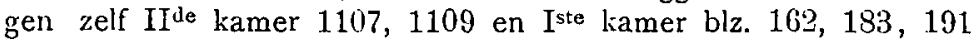
en 197. Interessant is de strijd tusschen den minister de Wa al Malefijt en Mr. van $\mathrm{Nierop.}$

1) Over 1910/1911 was dit percentage 10.53 over $1909 / 191010.20$, over $1908 / 190911.42$, over $1907 / 190811.22$ percent. 
uitkeering biedt zóó groot, dat men die niet spoedig zal prijs geven. Is het ten slotte zoo verkeerd, dat de fiscus weet, dat ook voor hem de auri sacra fames grenzen moet hebben, dat men de kip, die de gouden eieren legt, niet moet slachten? ")

Het bezwaar bestaat zonder twijfel, maar bij een matige heffing als hier werd in overweging gegeven wordt het door de voordeelen, speciaal door de mogelijkheid om een goede regeling der opcenten voor de gemeenten tot stand te brengen, ruimschoots opgewogen.

Te veel heb ik echter reeds van het geduld van den lezer gevorderd. Resumeerende meen ik te mogen concludeeren, dat eene hoogere belasting der naamlooze vennootschappen zich bij den nood der schatkist laat verdedigen -, dat wel dubbele belasting daarvan het gevolg zal zijn, gelijk deze trouwens ook reeds thans bestaat, maar dat dit geen reden mag zijn om het voorstel af te wijzen, doch dat men zich moet afvragen of door een andere regeling van het tarief het gewenschte doel niet beter zou kunnen worden bereikt.

11 Februari 1914.

Segers.

1) De Minister Bertling laat na om mede te deelen, hoe hij denkt over het door de vorige regecring ingediend wetsontwerp tot heffing van gemeente-opcenten op de bedrijfsbelasting van rechispersonen. Bijlagen 1912/1913 341. 1-3. Dáír werd voorgesteld een opcenten heffing van 100 , soms $160 \mathrm{pCt}$. wat, waar het Rijk $2 !$ pCt. hief een dividend belasting ten behoeve der gemeenten van 4 pCt. zou opleveren. $\mathrm{Nu}$ de heffing voor het Rijk $5 \mathrm{pCt}$. moet worden, zou 160 opcenten gelijk staan met een dividend-belasting voor de gemeenten van $8 \mathrm{pCt}$. Dit is overdreven. In het boven verdedigd stelsel zou men kunnen volstaan met den gemeenten te vergunnen op de dividend-belasting van 3 p Ct. 100 of in het uiterste geval 133 opcenten te heffen. $100 \mathrm{pCl}$. lijkt mij echter ruim voldoende. 